\title{
Analysis of Employees Performance Appraisal, Promotion and Mutationin Organizational Performance at Bank Sumut Medan, North Sumatra Province
}

\author{
Beti Nasution, Onan M. Siregar, Faisal Eriza \\ Faculty of Social and Political Sciences / Business Administration, Jalan Prof. Sofian No.1 Medan 20155 North \\ Sumatra \\ *E-mail of the corresponding author: betinasti@yahoo.com
}

\begin{abstract}
This research was conducted with the purpose; 1..To analyze the employees performance appraisal/assessment at Bank Sumut.2. To analyze the implementation of the promotion and transfer of employees at Bank Sumut.3. To analyze the performance of the organization of Bank Sumut. This research was conducted through a qualitative approach. Primary data were collected by in-depth interviews and observation. While the secondary data obtained through books, literature, internet, research findings and other resources that have relevance to the problem and research purposes, and also studied the documents such as the employee's career list, and others. Analysis used Miles and Hubermanmodels with activities such as: a. Data Reduction, b.The data Display and c. Conclusion / Verification. The result showed that 1 . The assessment of the performance has been good that is guided by performance management. Besides, it also provided coaching and counseling for employees who do not achieve the qualified performance2. Promotion held by considering performance appraisal but some are based on the element of subjectivity (like and dislike). Promotions are based on the appraisal of the performance makes employees feel satisfied because by being promoted they will get better income and prestige whchic affects to the employees' motivation to give the best for the organization/company.The implementation of employeesmutations/transfer build working spirit because there is an opportunity for promotion. 3. Bank Sumut organizational performance in 2014 and 2015 declined. It isbecause there are some employees didn't achieve the performance target for there is a promotion that was not based on achievement that caused the employees not motivated to achieve optimal performance. Some of teamworks performance also didn't achieve the target due to lack of cooperation and communication. The achievement of Bank Sumut Performance is facing constraints, both internal and external constraints.
\end{abstract}

Keywords; performance appraisal, promotion, mutation, organizational performance.

\section{INTRODUCTION}

Recently, the organization both the business and non-business operates in a very uncertain condition or face constant change. Changes caused technology development, globalization, the growth of rival organizations, the uncertain economic conditions, political, legal, plus changes in market demand caused the organization should continue to be able to adapt to change in order to remain able to exist in a state of uncertainty. In fact, 2014 was a year of full of challenges for a various industries, including the banking industry. Indonesian macroeconomic throughout the semester I - 2014 still face many pressures including a slowdown in economic growth, the current account deficit, liquidity became tighter, even though the inflation rate began to slow. Bank intermediation function in conditions of slow economic growth in general is becoming more challenging.
Bank Sumut Medan is one of the banks operating in the North Sumatra Province which of course also have to continue to be able to follow the changes that still exist and can continue to thrive in conditions of intense competition. Ongoing changes faced by the Banks, especially the Bank Sumut Medan mentioned above is heavy. Competitive conditions and uncertainty requires the organization should still be able to perform well. The organization's performance is influenced in part by the presence of competent human resources management. No matter how great other capital such as money, technology and others it will mean nothing if the human resources managementis not suitable.Dessler (1997: 3) explained that organizational performance is achieved by placing the right people in the right position, then motivating, assessing and developing human resources. Performance thus can be successful if the managers manage human resources through career development planning. 
The performance appraisal/assessment is required in order to know the gains that have been targeted. Research by MaimonaJabeen (2011) explains that performance appraisal is a very significant way in the excellent management of human resources. Performance appraisal/assessment to motivate employees to achieve performance, because assessments show the result of performance. Employees who reach the working target would receive incentives so that they gain prosperity, it will motivate employees to achieve performance. Promotions and transfers should be made to provide opportunities for employees to develop. Promotions can increase responsibility and also a raise in order to motivate employees to the spirit of the work. Mutations also expected to eliminate boredom, keeping or maintaining morale so the opportunity to improve his career or be promoted.Research by Agnetha Judas (2013) explains that the transfer and promotion of positions have an influence simultaneously on the performance of employees.

Bank Sumut held the performance appraisal based on performance manegement and also held the promotions and mutations in order to achieve the target of Bank Sumut Performance. However Bank Sumut's performance declined in 2014 and 2015. It is reported SIB newspaper (February 24, 2016) that "the Bank Sumutas Regional Owned Enterprises (BUMD) rated its performance has declined in recent years. Even accused of the worst performing, especially during 2014-2015 with a number of indicators on the marketing division and the process of managing third party funds (DPK) of the bank. Financial Services Authority (OJK) asked the management of Bank Sumut improve performance in 2015 considering the performance in 2014 slowed down. Share of Bank Sumut for example, still 10,06 percent of the total banking assets of North Sumatra in 2014 which amounted to $\mathrm{Rp} 233,09$ trillion. In fact, a regional bank that has been long time operated should have a larger share (Medan Tribune, Friday, May 22, 2015)

Based on the description of the background issues, the purpose of this research is; 1. Analyze the employeesperformance appraisal at Bank Sumut. 2. Analyze the implementation of promotion and transfer of employees in Bank Sumut. 3. Analyze the Bank Sumut's organizational performance.

\section{LITERATURE REVIEW}

\section{A.Performance assessment}

Assessment of performance (performance appraisal) is basically the key to developing an effective and efficient organization, for their policies or programs to better respond to the human resources inthe organization. According Mathis and Jackson $(2006$; 377) performance assessment/appraisal is the process of evaluating how well employees perform their jobs compared to a standard set, and then communicate this information to employees. According to Desslervol 2 (1997; 2) performance assessment can be defined as any procedure which includes; 1 , setting standards of performance, 2 , actual performance ratings of employees in relation to these standards, and 3, giving feedback to employees with the aim of motivating the person to eliminate slump continues to perform performance or higher. TeguhSulistiyani and Rosidah confirms that performance appraisal is basically one of the key factors in order to develop an organization effectively and efficiently, due to the policy or program performance appraisal, means that the organization has leveraged well the human resources in the organization $(2009 ; 275)$.

\section{B.Promotion and Transfer}

Promotion. Promotion is an employee career development effort. Promotion is when an employee moved from one position/ job to higher another position/job in the hierarchy by greater responsibility and greater income (Dessler, 1997; 299). Simamora $(1995$; 587) said promotion is the transfer of an employee to a position higher level in the organization. At the time promoted employees generally face increasing demands expertise, capabilities and responsibilities. Instead, employees generally earn a salary increase and sometimes benefits, authority and greater status.

Mutation. Mutation means switching from one office to another position, usually without changes in salary or rate. According to Dessler (1997; 62);

"Mutation means switching from one position to another position, usually without changes in salary or rate. Employees can ask for a transfer for personal enrichment, to get a more interesting job, to get greater comfort - working hours, workplace, and others - or to gain 
positions that offer greater possibilities for progress. The employer may transfer an employee to vacate a position at this position is no longer needed, to fill vacancies where he was needed, to retain a senior employee (shift a less senior), or more generally to get a better match in the company ".

Siagian, Sondra (1994; 171-172) said that a mutation to the term the task switching. Siagian said,

"Task switching can take one of two forms. The first form is the placement of a person on a new task with responsibility, hierarchical position and income is relatively similar to the previous status. In such case, an employee was placed on a new work unit other than the unit of work in which a person during this work. Secondly, task switching, if this method is adopted, meaning an employee perform the same or similar tasks, income has not changed and the same responsibilities. The second approach is of course only possible if the organization has taken various work units across multiple locations ".

\section{C.Organizational performance}

The term performance is the translation of performance that is often interpreted by scholars as the "appearance", "working demonstration", or "achievements". According to Wibowo (2007; 7) the performance is the result of work that has a relationship with the organization's strategic objectives, customer satisfaction and contribute to the economy. Benardin and Russel in Keban (2004: 192) emphasize the performance of the resulting outcome is obtained after a job or activity carried out during a certain period of time. Thus, the performance simply refers to a series of results derived by an employee during a certain period and did not enter the personal characteristics of employees who rated.

Performance can be distinguished on individual performance, group performance and the performance of the organization (institution). Individual performance illustrates the extent to which a person has been carrying out a duty that can deliver the results set by the group or institution. Performance groups illustrates how far the group has carried out activities principally so as to achieve the results as determined by the institution. Performance of the organization (institution) regarding how far the institution has been carrying out the principal so as to achieve the vision or mission of the institution (Keban, 2004; 193).

\section{RESEARCH METHOD.}

This study uses descriptive method with qualitative approach. The primary data collection techniques used in depth structured interviews by using tools such as tape recorder, observation and using questionnaires. Secondary data collection by studying books, related literature and documents. The analytical method used is qualitative analysis by Miles \&Huberman Model and quantitative data were analyzed using performance importance matrix.

\section{RESULT AND DISCUSSION}

\section{A.Performance Assessment/Appraisalat Bank Sumut}

Bank Sumut has implemented performance assessment through performance management that has been designed as good as possible beginning with the planning phase of work, working counseling,further assessment phase of work. Planning the performance is done so that every officer and employee has the performance goals for the year ahead. Performance planning is done every year between the end of October to December after obtaining work unit corporate goals are reflected in the Annual Work Plan and Budget (RKAT). After the performance planning the next step is carried out by the performance guidance supervisor or manager immediately so employees can achieve performance goals. We evaluated the performance of the individual by direct supervisor.

Implementation of performance assessment at the Bank Sumut is done by comparing the planned achievement of performance standards with the performance of employees. Performance goals set for a period of one year are set well on structural and functional officers and employees. Performance goals set for the operational target of structural officers, such as operational objectives, work process improvement objectives and targets for improvement of human resources. Performance goals set for professional staff and employees are the operational objectives and targets for improvement of work processes. Determination of the performance targets and key for performance assessment implementation of an objective performance assessment. If no 
performance goals clear there can be performance appraisal which is not objective (like and dislike) and does not clear the consequences of employee and can not be used as a source of information for employees' career development, employee development is not going well so it does not motivate employees to work better and ultimately leads to the difficulties of organizational development.

The results of performance appraisal is information that can be used as one of the key factors the development of an effective and efficient organization. Because with the performance appraisal we can know the performance achieved by the individual employee, in the sense of how much the employee's contribution in achieving the goals and objectives of the organization. This information provides a description of the organization's human resources which can be seen the real conditions of the employees seen from its performance. Performance appraisal results can then be used to develop reward programs and compensation, prepare a capacity building program for employees, knowing and an input for employee career planning patterned and ultimately to the development of the organization.

Feedback. Employee performance appraisals are followed up by the provision of information to employees about their performance at this year (feedback). Employees who know that their performance doesn't achieve the target are given the opportunity to improve their performance. Employees normally will try to improve their performance so that in the future they can achieve the targettedperformance - because if employees do not achieve performance goals will acquire the consequences. As the information obtained from the Bank Sumut knowledge report that if the employee gets a minimum score $B$ and then will be able to obtain a salary increase in accordance with the COLA (Cost Living Adjustment), periodic salary increases and employee loan facility. If you scored under $B$, only the right to receive salary increases in accordance with the COLA. (Do not get a regular salary increases and employee loan facility). The implementation of these consequences can certainly motivate employees to strive to achieve performance in line with the goals that have been set.
Coaching and Counseling. Bank Sumut provide coaching and counseling that is a facility to discuss employee performance problems and also consulting performance for employees who do not achieve performance goals. Employees who do not achieve the performance are given the opportunity and time to talk about the achievements of their performance, why employees do not achieve performance. It can be submitted to the direct supervisor. Performance coaching and counseling is important to know what the cause of not achieving performance targets. There are two types of performance guidance which are applied at the Bank Sumut, namely; 1. Formal Performance Guidance; conducted twice a year and documented in form of performance guidance, the period I (April) and the second period (August). 2. Informal Performance Guidance; made at any time required, can be feed back spontaneous or planned coaching and counseling.

The availability of facilities and performance guidance is an attempt of Bank Sumut to help employees improve performance target which is not reached yet, and find solutions of performance problems. The performance assessment process is not a fault finding employees. Not achieving the performance targets not only because unskilled and the inability of employees so that if there are employees who do not achieve performance goals they need education and training. Not achieving the performance targets could be several causes; such as the lack of adequate facilities and infrastructure to do the job, lack of direction and motivation from superiors, unfair compensation, perhaps a lack of communication between supervisors and subordinates so that employees do not get clarity on the work expected of the employee. It could be also because of family problems which disturb the employee's mind so the impact on jobs. According to Mathis and Jackson (2006; 308) ...... employee performance can be decreased but not for lack of ability or lack of skills, but can be caused for example boredom, inadequate compensation design work and others. By using performance consulting approach then non-training factors, such as compensation, organizational structure, job design, and physical working conditions are also considered. Therefore, to find out why the employee's performance is not achieved, it needs coaching and counseling to find the root of the problem is not the achievement of performance goals and to find appropriate solutions. At this 
consultation a few things that need to be discussed what factors that cause employees to fail in reaching the target, what kind of difficulties in the implementation of the work and what the boss do to be able to overcome the problems encountered. If the direct supervisor (leader) can not find a solution faced by employees, he can ask for advice from human resources manager.

\section{B.Promotion And Mutation/Transfer at Bank} Sumut

Promotion. Implementation of promotion in the Bank Sumut, there are based on performance, service period but there is also the element of subjectivity (like and dislike). Promotion at Bank Sumutwhich is based onperformance achievement, the employees are satisfied and increase morale for the promotion of employees got a better income, enhancing the prestige also feel more proud. Promotions also motivate employees to give their best for the company and even according to the findings at the field (Bank Sumut), after the promotion the employees want to be better at work. Promotion gives benefit/advantages both the organization and for employees. This is consistent with the findings of Simamora (1995; 587-588) that the sale serves several purposes and provide benefits to the company and the employees;

"First, the promotion allows companies to leverage the expertise and abilities of employees as high as possible. Promotional system that effectively allows an organization to match the needs that will be continuously competent personnel with employees' desire to apply the skills they have developed. Second, the promotion is often given to reward excellent performers. Employees who are motivated to appreciate the high level of performance if they feel that the performance led to a promotion. Third, research shows that opportunities for promotion and a high level of job satisfaction correlated highly significant. Employee promotion system that can effectively lead to greater organizational efficiency and higher employee morale levels".

However, from field findings, we obtained information that the implementation of the promotion Bank Sumut, some of promotion there isbased element of subjectivity (like and
dislike).The promotions not based on performance achievement will make employees get difficulties in their performance. This is due to the employee may not have competence in the field of work and also the employee was not motivated to perform well - the employees who get promotion because of the element of subjectivity. Promotions are not based on anything to do with the performance of assessors. Assessor only done by the Human Resources manager and also the direct supervisor. To avoid any element of subjectivity, the assessment/appraisal should not only be done by the direct manager and human resources manager, but assessment can also be done by peers, and top-level managers. As stated by Iswanto $(2004 ; 5: 40)$ that the assessor can consist of employees who are assessed, peers, customers, and top-level managers.

Assessors consisting of various parties will be able to minimize subjective assessments so as to make employees believe in the existing assessment system. The assessment also should be open/transparent. As stated by TeguhSulistyani and Rosidah (2009) that "the assessment system developed should be covered by a transparent system, so employees can find out how the assessment results to himself. Data assessment needs to be communicated to employees transparently. Besides, also employees were given space to present feedback on the results of the vote ".

Mutation. Mutations atBank Sumut implemented in order to reduce boredom and build morale. Routine work every day with monotonous work situations, the working environment and working conditions are the same each day will lead to saturation and could have an impact declining morale and impacted on not achieving the good performance.

Implementation of Mutation atBank Sumutdone in two forms. The first is to switch tasks with different fields of work of previous work but responsibilities, and salary level equal to the previous job. The second switch locations where the work, authority and responsibility and salaries are the same as the previous job. Mutations well with the shape of the first and second forms are equally able to build morale. Mutations to the first form gives happiness because there is a new task which is different from the old task so that there is a new challenge where employees are motivated to learn. Mutations with the second form also foster the 
spirit of a new work for the implementation of these mutations besides employees find a new atmosphere, new friends, they can also provide opportunities for promotion. Implementation of the mutation with the second form according to the human resources manager is not a punishment but it is one way to improve the performance so as to give an opportunity to the employee for promotion or mutations/transfer is a way for promotion. The explanation of this mutation stimulates employees work with more passion because it would provide the opportunity for promotion.

\section{C.Organizational Performance of Bank Sumut}

Organizational performance is an accumulation of the success of employee performance and also the performance of each division within an organization. The achievement of the organization's performance can also be seen from the success of achieving the organizational vision. Based on field findings that not all performance can be achieved perfectly. Achievement of performance by employees varied depending on each other's work. Achievement of the performance of each employee are not only caused by individual employees but sometimes the achievement of employee performance also depends on other divisions that are related to the work of employees.

Every employee atBank Sumutmanages as hard as possible to achieve the performance set for impact on the remuneration to be obtained. Regular/routine performance can generally be achieved by every employee in accordance with the set targets.But in addition to the routine work, employees also have a job that is project based such as issuing new products. Based Project is done in teams between divisions and the determination of the workload carried by the team. The successful resolution of this team work depends on their teamwork, coordination and good communication.

According to Gibson, Ivancevich and Donnelly (1993) variables that affect job achievement or the performance is the individual variables, psychological variables and organizational variables. Individual variable consists of abilities (intellectual), skills, age, gender and others. Psychological variables consist of perceptions, attitudes, personality, and motivation. While variable organization composed of resources - resources, leadership, rewards - rewards, structure, design and communication work. Based on the opinion of Gibson, Ivancevich and Donnelly that organizational performance can be achieved not only the good individual variables or only goodvorganizational variable or just a good psychological variables. But the performance is influenced by the interaction of these three variables.That is when the organization seeks the achievement of the performance of the individual variables must be good,then the organizational variables should also be a good,so that psychological variables that ultimately achieve organizational performance. If one variable is not good, it will interfere with the achievement of the performance.

Individual employees variable of Bank Sumut seen by level of education is the level of employee education is dominated by Bank Sumut on education strata $S 1$, then the strata $S 2$, then high school. The level of education can be used as a benchmark to measure the ability of (intellectual) skills, and behavior. In terms of age, employees of the Bank Sumut is still in productive age. From the organization of the Bank Sumut also provide the reward for the employees who achieve good performance and Bank Sumut also provides counseling and coaching facilities to the employees that didn't achive good performance. Based on Annual Reports $(2015$; 103) Bank Sumut is also trying to build a conducive working environment to support performance improvement. Bank Sumut is committed to creating a work environment in the form of safe working environment, comfortable, and capable of improving the quality of work. Bank Sumut also ensure Implementation of Safety and Health Management System (SMK3) that aims to protect employees, customers, asset, business partners and the environment from potential hazards that may occur.

Performance of Bank Sumutdecreased in 2014 and 2015 if studied deeply revealed that in fact there were some employees didn't achieve the performance because there were some promotions not based on performance achievement which caused some employees didn't have motivations to achieve the performance. The teamwork performance also didn't achive the performance due to lack of cooperation, coordination and communication. Achievement of the performance of Bank Sumut is facing challenges, both internal and external 
constraints. Internally, there are still variables that have not been as good as the organization; application segregation of duties in the bank's operations have not been effective, resources (technology is not adequate), the system operating procedures (SOP), which does not yet reflect the responsibility of each and big organizational structures slow down the working process of which will affect the perception and motivation of employees - it has implications for not achieving the organization's performance. Then the external conditions are always changing which requires organization to continuously respondsthe changes.

\section{CONCLUSION}

1. The Assessment of the performance has been good that is guided by the phases of performance management; Performance Planning, guidance Stage Performance and Performance Assessment Stage, which serves as a monitoring tool to provide feedback to employees. Besides, it also provided coaching and counseling for the employees not achieve the good performance.

2. Promotion held by performance, employment periods, but some are based on the element of subjectivity (like and dislike). Promotions are based on performance makes employees feel satisfied and increase morale/spirit for the promotion the employees got a better income, enhancing the prestige of the impact on the motivation of employees to provide the best for the company. Implementation of the mutation whether by switching position or locations are equally improve morale because it gives the opportunity to be promoted.

3. The Bank Sumut organizational performance in 2014 and 2015 declined. It due to some of the employees didn't achieve the performance for there were some promotions not based on performance achievement, the teamwork performance also didn't achieve performance for lack of cooperation, coordination and communication. Organizational performance achievement ofBank Sumut is facing challenges, both internal and external constraints.

\section{REFERENCES}

Anwar PrabuMangkunera 2009, HR Performance Evaluation, Bandung, PT RefikaAditama

Bacal, Robert, Performance Management, interpreted bySurya Dharma and yanuarIrawan, Publisher PT GramediaPustakaUtama, Jakarta, in 2001.

Benardin, Hj. and Russel, 1993 JEA, Human Recources Management an Experimental Approach, International eddition.

Dharma, Surya, 2004, Performance Management, Philosophy Theory and Practice, the Directorate General of Higher Education, 2004.

Dessler, Gary, 1997, Human Resource Management, Human Resource Management 7e, vol 1 interpreter Benjamin Molan, PT Prenhalindo, Jakarta,

Management, 1997, Human Hesource
Management, vol II, interpreter Benjamin
Molan, PT Prenhalindo, Jakarta.

Drucker, 2001, The Organization Of The Future, Publisher PT.Elex Media Komputindo, Jakarta Gramedia group.

Ghozal, S \&Barlett, C, 1995, Changing The Beyond Rule of Top Management Systems to the People, "Harvard Business Review.

Gibson, Ivancevich, and Donnelly, Organizational Behavior, Structure and Process, Editor, Agus Dharma, vol 1, Jakarta, Erland 1993.

Iswanto, Yun, 2004, Human Resource Management, the Open University.

Mangkuprawira, Sjafri 2004, Human Resource Management, Ghalia Indonesia, Jakarta.

McKenna, Nic Beech, 2002, The Essence of, Human Resource Management, Pearson Education Asia Pte, Ltd., AndiYokyakarta.

Mhatis, L Robert and Jackson, John, 2001, Human Resource Management, interpreter: Jimmy Sadeli and BayuPrawiraHie, Volume I, Salemba Four, Jakarta.

2002, Human Resource Management, interpreter: Jimmy Sadeli and BayuPrawiraHie, volume II, Salemba Four, Jakarta. 
2006, Human Resource Management, interpreter: Diana Angelica, 10th edition, Salemba Four, Jakarta.

Moeheriono 2009, Competency-Based Performance Measurement, first printing, Ghalia Indonesia, Jakarta.

Nazir, Moh., 1988, Methods, Jakarta: Ghalia Indonesia

Simamora, Henry, 1995, Human Resource Management, Publishing Section, School of Economics YKPN, Yokyakarta.

Siagian, Sondra P, 1994, Human Resource Management, Earth Literacy, jakarta.

Sugiyono, 2002, the Administrative Research Methods, Bandung, Alfabeta.

2010, Qualitative and Quantitative Research Methods $R$ \& D, Bandung, Alfabeta.

TeguhSulistyani and Rosidah 2009, Human Resource Management, Concepts, Theory and Development In the Context of Public Organization, Graha Science.

Wibowo, 2007, Performance Management, Issue one, Jakarta.PT King GrafindoPersada

\section{Journals}

EMBA Journal Vol.1 3 June 2013, p. Nitta 1019.Verra Turere titled Influence And Training of Performance Improvement employee On Agricultural Technical Training Institute Kalasey.

Global Journal of Management and Business Research.Volume 11 Issue 7 July 2011. Version 1.0 Type: Double Blind peer reviewed International Research Journal. Publisher: Global Journals Inc. (USA). Print ISSN: 0975-5853. Raja Abdul Ghafoor Khan, Furqan Ahmed Khan. "Impact of Training and Development on Organizational Performance".

European Journal of Business and Management www.iiste.org

ISSN 2222-1905 (Paper) ISSN 2222-2839 (Online) .Vol 3, \# 4, 2011.MaimonaJabeen, "Impact of Performance Appraisal on Employees Motivation".

\section{Research.}

Research MartoTambunan (2015) with the title Effect of Education and Training on Employee Performance At BNI Branch office ofPadangSidempuan City 